\title{
A Survey on the Causes of Non-English Majors College English Learning Burnout in a Local University in China-A Case Study of Anhui University of Science and Technology
}

\author{
Yaoqin Zhang \\ Anhui University of Science and Technology, Huainan, Anhui, China
}

\begin{abstract}
This paper aims at explaining the college English "learning burnout" phenomenon with descriptions and statistics from a survey conducted in Anhui University of Science and Technology in October, 2018. The survey was mainly geared to investigate on the causes of college English "learning burnout" syndrome among freshmen and sophomores. The analyses of the causes are made from both learners' and teachers' perspectives. With some solutions are presented in the end. It is hoped to help to solve and enlighten the improvement of College English learning and teaching in local science and technology universities in China.
\end{abstract}

Index Terms - non-English-major students, college English learning burnout, local science and engineering Universities

\section{INTRODUCTION}

\section{A. The Term "Burnout."}

The term "burnout" was originated in Graham Greene's novel A Burnt-Out Case (1960), in which a desperate architect quits his job and escapes the African jungle (cited in Maslach, 1976), it was for the first time, "burnout" was used as a term referred to a psychological syndrome which resulted from chronic stressors on the workplace (Maslach et al., 2001). In 1974, Freudenberger (1974:p.159) first used the word "burnout" to describe a social phenomenon, in which human service professionals were so exhausted that they could no longer perform their tasks effectively. From that time on, a lot of studies on "burnout" focused primarily on studying this concept in terms of how it related to occupational work (eg. Maslach, Schaufeli, \& Leiter, 2001). In addition to burnout among professionals, burnout among students has lately become a field of research. The term "learning burnout" first appeared in works of Pines \& Katry in 1981, as it puts, "learning burnout" is a phenomena which students have suffered from the learning process; In 2002 , Schaufeli and other scholars started to regard "learning burnout" as a kind of emotional loss; and then in 2005, Chinese scholars Yang Lixian and Lian Rong put forward a point of view that "when students are not interested in learning or lacking of motivation to learn but have to, they will feel tired, fatigue, frustration and setbacks. This results a series of inappropriate behaviors. Such a state is known as the learning burnout."

\section{B. The Background of the Survey}

The survey is based on a serious decline in students' liking for college English classes, just as the figures showed in table 1 . 
TABLE I.

LIKE OR DISLIKE COLLEGE ENGLISH CLASS

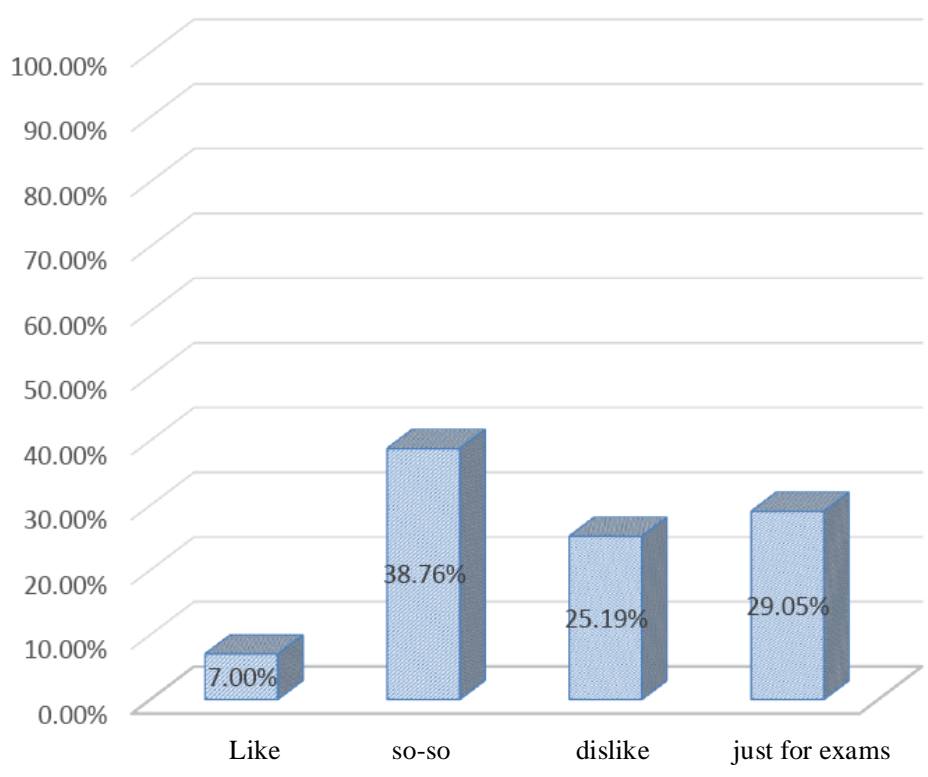

From figures in table 1 we can see the severe situation of college students' attitudes towards College English class. Over $50 \%$ of the participants involved showed negative emotion toward college English class, and only $7 \%$ of the participants stated out their positive emotion toward English class. As a teacher who teaches college English, the author also wants to know what causes the lack of interest of college students in English learning. Through the investigations, the author finds that the reason why college students lack interest in College English classroom is that they are tired of English learning. But because the external pressure from society as well as the job market, they have to learn, which leads to learning burnout syndrome. Just as Yang Tao has presented in 2010, that college English learning burnout is a kind of psychological syndrome which is caused by the differences between the content, process or the result of English learning activities and expectations of the learners themselves. It features in exhaustion, indifference to English learning and the negative emotions related to decadence in English learning. English learning burnout syndrome has hindered students from learning English well, thereupon it influences students' personal improvement in the long run. Particularly, under the current College English teaching reforming circumstances, it is crucial to understand the causes of students' learning burnout.

\section{THE STUDY}

Here comes the survey. It consists of questionnaires and interviews. The questionnaires were conducted among the non-English major students of the 2018 freshmen and 2017 sophomores in Anhui University of Science and Technology, with answering questions like, how do you think of college English, is English important for your future career planning, how do you behave in College English classes, and do you like English class and what is your purpose of learning English, and so on. Questionnaires were put on the internet with multi-order sample; students could answer the questions with their Smartphone. There were totally 25 questions in the questionnaire, most of which are selected. The questions involved in the questionnaire ranged from the students' attitudes toward English learning to college English teaching, as well as to the college English teaching effect in the class. Interviews were conducted among the 28 front-line college English teachers. The author investigated on the students' performance in English class, asked such questions as, did your students previewed before class, did your students behaved well in the class and did your students actively complete all the homework after class, etc. this study aims at investigating on the causes of the learning burnout phenomenon among college English class, and then giving out some solutions on how to solve it.

\section{A. The Aim and the Objectiveness of the Study.}

The present study has set itself the objective of focusing on the presentation of the wealth of data which emanated from the students' questionnaires and provided rich insights into non-English-majored students' actual burnout situation and to seek intervention. Nevertheless, it should be put forward that the learning burnout situation has not been limited to the college English class only, the learning burnout situation is also common among other courses.

In particular, the basic objectives of this part of the research project were:

To present the current psychological problems prevalent in College English learning;

To identify the causes of negative emotions toward college English learning;

To give out suggestions on what should be done to buffer the learning burnout. 


\section{B. The Participants}

The participants involved in the study were 361 non-English majors of Anhui university of Science and Technology, Huainan, Anhui province in China. Of them 57.62\% were male and 42.38 female. Their age range varied; however, the majority of them (74.5\%) were 18-22 years old, as for the interviews, 28 front-line college English teachers were interviewed in the study.

\section{Research Methods and Tools}

A multi-method approach which involved both quantitative and qualitative research methods was adopted in the study. Data were collected through the students' questionnaire which included closed- and open-questions and was administered to 361 students. Moreover, semi-structured interviews were conducted with 28 college English teachers in an attempt to gain more meaningful insights into the situation.

\section{Data Analysis}

The data derived from the questionnaires and interviews were analyzed by using descriptive statistical methods. Frequencies and percentages for all items of the questionnaires were obtained.

\section{Findings OF THE QUESTIONNAIRE}

\section{A. The Current Situation of College English.}

With respect to the attitudes toward college English, a considerable number of the participants $(90.03 \%)$ stated the importance of learning English. Those non-English major students believed college English was very important for their future career. For instance, over $90 \%$ of the 361 participants have agreed that English is very important in finishing their college studies and providing them with good job opportunities in the future, and $62 \%$ of those polled said they thought college English was practical, but it was only practical in passing cet 4 or cet6, which the certification could help them in finding a good job opportunity, therefore in answering their purpose of learning English, over $72.02 \%$ of the respondents viewed learning college English as the necessity for planning their future career. Regarding the practicability of English, the participants declared it is practicable either "very practical"(23.55\%) or "practical" (39.06\%); as for the purposes of learning English, 78.67\% of the participants asserted that they learned it for mastering a useful language skill, while $55.12 \%$ believed in learning it for passing exams, only $28 \%$ of the participants considered it is of great help in understanding the European and American culture. Through the statistics we can see, college English is still believed to be very useful in helping shape the participants' future career.

\section{B. The Causes of Negative Emotion toward College English Learning}

1. The conventional teaching methods caused students' antipathy against learning English.

The survey data found that, the college English teachers mainly taught vocabulary, grammar and analysis of the structure of both the sentence and paragraphs in their classes. This kind of teaching methodology, we call it conventional teaching methodology, makes students in a state of being listened to and being forced to learn. For instance, in answering "what does your college English teacher focus on?", over half of the 361 participants have stated that their English teachers would teach them grammatical knowledge, and $62.05 \%$ of those polled said their English teachers would teach them vocabulary, and over $72 \%$ polled students stated that their English teachers would focus on the analysis of sentence structure, and 34.9\% of the participants said their English class would focus on the examination skills, and only $15.24 \%$ of the participants stated that their teachers would focus on the cultural background knowledge. Through the statistics we can see, the present conventional college English teaching method makes students in a state of being listened to and being forced to learn. Thus this kind of state has caused students' antipathy against learning English, and gradually against going to college English class, which, in turn, reflected out students' lacking interest in learning English.

2. The purpose of passing the examinations dispirited students' interest in learning.

The present examination evaluation system depressed students' enthusiasm toward college English learning. For the examination-oriented education system, students mainly focus on the grammatical study, for instance, according to the data, there are more than $73.96 \%$ of the respondents believed that vocabulary was their learning focuses, and over $65.93 \%$ of the respondents thought training in listening, speaking, reading and writing skills were their learning focuses. So when answering “what do you hope to achieve through college English learning?" over 72\% polled participants stated that they wanted to pass CET4 or CET6, because the cet4 or cet6 certifications will help them find a good job, and correspondingly improve personal social status. Therefore it is naturally for them to learn English with focuses on learning the skills in dealing with examinations as well as the grammatical information contained in the texts. This causes their English class to be monotonous and tedious. Another aspect of the reason is that, although all the students work hard in college English, the exam results turn out to be undesirable; this also depressed most of the students in learning English. According to the data, nearly half (49.02\%) of the participants were unsatisfied with their scores, and about $40.17 \%$ of the participants were disappointed with their college English learning. According to Achievement Motivation Theory, the probability of success, which is the most likely choice for students, is about $50 \%$. If students think that no matter how hard they work, they will certainly fail, which will cause their learning motivation at a very 
low level. Gradually they will lose interest in learning.

\section{FINDINGS OF INTERVIEWS}

Rich insights into the college English learning burnout were provided through the interviews of 28 college English teachers which complemented the findings of the questionnaire. Through the teachers' interviews we can see the learning burnout phenomena had closely related to the foundation of English learning, frustration in English learning, and the lack of English learning atmosphere. For example, there were 25 out of 28 teachers believed the low proficiency and weak foundation in the basics of English knowledge, as well as incapability in self-learning had caused students' lacking interest in learning college English; as for speaking and listening skills, almost all the teachers believed that poor pronunciation led the students' lack of courage to express in English, which directly or indirectly led to their low proficiency in both listening and speaking. The interviews also showed that students commonly relied heavily on their teachers in English learning. They usually accepted knowledge passively and could not think actively in the class, while the current college English teaching mode gave top priority to students-centered mode which required high self-learning capability and strong self-control ability of students in the class. Because of the weak learning foundation and the lack of autonomous learning ability, it was often difficult for students to adapt to the college English teaching mode, which led to the decrease of interest in learning.

Also, through the interviews we can see, teachers insisted that the lower academic achievement constantly hampered students' interest and self-confidence in learning. Students feel frustrated in English learning in the class. College English teachers mostly teach in full English or more English, which makes it difficult for students to adapt to, exacerbates the frustration. Students lack interest in English learning. They are half-hearted in class and seldom carry out corresponding consolidation exercises after class. The influence of English learning atmosphere, learning atmosphere is an important factor affecting students' learning English, a strong learning atmosphere can improve students' enthusiasm for learning English. Schools attach importance to creating a good atmosphere for learning English, students will have the desire to learn English well. If schools do not attach enough importance to it, or only emphasize professional learning, then students will be inert in learning English and easy to cut classes. Besides, as a front-line teacher in College English class, the author also often sees this situation in the course of class: the whole class is basically a teacher singing a monologue, the participation of students is not active, on the contrary, some students are not even interested in College English learning, some students are drowsy in class, some students do not leave their hands on their mobile phones, and so on. These behaviors of students bring great difficulties to teaching activities, and even make teaching activities difficult to carry out. There are 23 out of 28 teachers interviewed stated that the College English classroom atmosphere is dull and students' awareness of participation is very weak. It is not uncommon for teachers to engage in selflessness while students are absent-minded underneath.

Additionally, according to the interviewed teachers, although there are many college students eager to learn college English well, but they still haven't found proper learning methods. For example, while learn college English, they tend to memorize new words today, look at the grammar tomorrow, practice listening and speaking the day after tomorrow, for those students, they are lacking of systematic learning, what's even more, they have no feasible English learning plan. Therefore, it is easy for them to fail when it comes to the exam. Correspondingly, the setbacks will cause them to feel they have a weak English foundation, so it is natural for them to restart learning from scratch. As a result, time is wasted on the inefficient vicious circle of knowledge, but the situation has not improved at all, which leads to despair and completely loses interest and confidence in the course of College English learning. The reason for this phenomenon is that students' long-term interest in English learning has been exhausted by countless examinations and rote-learning methods, and even become bored of learning.

To summarize, 1) although almost every non-majored college students believed English to be very helpful in their future career planning, they felt they were forced to learn English well, which, for a college student who has just passed the college entrance examination, now, without pressure coming from both parents and teachers, was difficult for them to focus on the tedious English learning, therefore, they become bored of learning English; 2) there are differences existed in college students' English proficiency and autonomous learning ability, some students show low learning ability in English learning. For instance, some students try hard to learn English in the very beginning, but because of the improper learning methods, they made no obvious progress in learning, they get frustrated, and then their interest in learning English becomes weaker and weaker, therefore it is easy for them to show strong inferiority complex in English learning, gradually, those students will generate a sense of despair and a complete loss of interest and confidence in the course of College English learning; 3) there is no proper motivation in learning English. The conventional teaching method and the present examination evaluation system bruised their enthusiasm in English learning away, and their senses of achievement have been contused by the repeated failure in English class. Besides, after entering college, their major becomes more important than other courses, they pay much more attention and energy to their major-related courses, and less attention to the humanist aspect of learning, English is a language, it belongs to humanities, which seems has nothing to do with their natural science oriented subjects, therefore they become less willing to come to English class, and lack of interest in learning English. 
Due to the various reasons listed above, students are in a dilemma. For in one aspect, college English is of great importance for their future career, while in another aspect, they tend to be lacking interest in English. Students are insensitive to English class, they are forced to come to English class, therefore it is natural for them to cause antipathy against English class, gradually, they will against go to college English class. While out of social needs, they have to pass cet 4 or cet 6 examinations if they want to have a better future career, thereupon, it seems someone forced them to learn. This kind of forceful feeling, together with their setbacks in learning, make them feel tired, fatigue, frustration, which is what has been called "the college English learning burnout." Just as Yang Lixian and Lian Rong put it— "when students are not interested in learning or lacking of motivation to learn but have to, they will feel tired, fatigue, frustration and setbacks," in fact, it is a kind of psychological syndrome, "It features in exhaustion, indifference to English learning and the negative emotions related to decadence in English learning."(Yang Tao) this kind of emotional exhaustion was caused by the decrease or lack of interest in learning, the decrease of self-efficacy or the pressure of heavy learning tasks.

To conclude, after at least six years of good or bad English learning experience before entering to the university, with the changes of learning environment and learning purposes, non-English major students commonly tend to have college English learning burnout syndrome. This learning burnout syndrome plays a negative role both in the learning of learners themselves and in the teaching of teachers.

\section{SUGGESTIONS FOR IMPROVING}

As a major obstacle in college students' learning process, learning burnout is a very negative emotion and passive psychological syndrome, it is very harmful to students' learning and life. To a large extent, it affects students' English learning, and then affects students' personal development and the better personal development. If teachers can attach importance to students' burnout in English learning, and with might and main to change this phenomenon, their teaching effect will be better, students' learning will be better, either. So how to solve this problem is particularly important. In order to solve English learning burnout syndrome, this paper also presents several suggestions for both college English teachers and non-English majored students.

For college English teachers, the first and foremost thing for them to alleviate learning burnout syndrome is to consider what should be taught in college English class? The paper believes in the attitude. After all, attitudes decides everything, therefore the conventional English classroom teaching mode should be converted into drawing students' interest into learning English. Particularly speaking, the modern intelligent teaching method should be energetically implemented into English classroom and the multi-media equipment with the intelligent situational simulation teaching methodology should be utilized to lead students to step into a native language context, and help students create the real scene of language learning, and make students integrated into the English classroom actively and quickly. The second thing for college English teachers to alleviate learning burnout syndrome is to push forward the current Examination-oriented Evaluation System reformation. To advocate a kind of evaluation method which not only evaluates and tests students' English learning achievement and level according to their performance in the class and after their completion of homework after class, but also requires the college English teachers not confine themselves to simply testing students' foreign language knowledge, but pay more attention to assessing students' ability to communicate in English. With this kind of assessing system, it can not only encourage students to participate in the classroom, improve their confidence in language learning, but also can improve their sense of achievement and recognition, which are very useful in alleviating students' learning burnout syndrome. The last one for college English teachers to alleviate English learning burnout syndrome is how to create a pleasant and harmonious classroom atmosphere. Happy and harmonious classroom atmosphere is very important to protect students' learning motivation. More and more scholars believe that only by reducing the control of students and providing them with opportunities of autonomy, initiative and self-expression as much as possible, can we create an environment for more effective learning and stimulating students' learning motivation. Therefore, in teaching, we should create a learning atmosphere that makes students feel safe, tolerant and conducive to their development, show sincere concern for each student, highlight the value of learning process and task, and do not pay too much attention to learning results, so as to reduce students' anxiety. With a pleasant and harmonious classroom atmosphere, students will more likely to engage in learning English, and therefore alleviate English learning burnout syndrome.

For the non-English majors, the first thing to alleviate English learning burnout syndrome is to give full play to autonomous learning. The so-called autonomous learning here refers to a modern learning mode corresponding to traditional acceptance learning mode. As the term suggests, it takes students as the main body of learning, and students can achieve their learning goals by means of independent analysis, exploration, practice, questioning and creation. As the Outline of Basic Education Curriculum Reform (Trial) has put it, the specific objectives of basic education curriculum reform is "To change the current situation of curriculum implementation which emphasizes too much on accepting learning, memorizing by rote and mechanical learning, we should advocate students' active participation, willingness to explore and be diligent in doing so, and cultivate students' ability to collect and process information, acquire new knowledge, analyze and solve problems, as well as their ability to communicate and cooperate." through advocating students to learn how to study independently, willing to learn and form a strong learning motivation, increase interest in learning, make students willing to learn and enjoy learning, solve the problems of students' 
weariness and truancy, which correspondingly alleviates students' English learning burnout syndrome. The second thing for students to alleviate English learning burnout syndrome is to have a clear learning purpose and correct learning attitude. Different learning purposes will inevitably lead to different learning effects. Generally speaking, students with definite and long-term learning purposes work harder and learn more durably in the learning process. Only by clarifying the purpose of learning, can students turn "I want to learn" into "I want to learn", which will need to be translated into motivation. The ultimate goal of College English teaching is to cultivate students' practical ability to use language. Only when students combine "instrumental" motivation with "integrated" motivation and use English as a communication tool to learn, master and use it, can they have a correct attitude towards learning and improve their enthusiasm and consciousness in learning.

The last thing for students to alleviate English learning burnout syndrome is to overcome anxiety and build self-confidence. The word "anxiety", as it puts it in https://en.wikipedia.org/wiki/Anxiety, "Anxiety is an emotion characterized by an unpleasant state of inner turmoil, often accompanied by nervous behavior such as pacing back and forth, somatic complaints, and rumination." (Walker EF, Rosenhan DL) It is not the same as fear, which is a response to a real or perceived immediate threat, whereas anxiety involves the expectation of future threat. "Anxiety is a feeling of uneasiness and worry, usually generalized and unfocused as an overreaction to a situation that is only subjectively seen as menacing." (Bouras N, Holt G, 2007.) It is often accompanied by muscular tension, restlessness, fatigue and problems in concentration. Therefore anxiety is a kind of negative emotion, which refers to the nervous and fearful emotional state formed by the individual's failure to achieve the expected goal or overcome the threat of obstacles, which frustrates his self-esteem and self-confidence, or increases his sense of failure and guilt. English learning is an activity that easily threatens self-esteem or self-confidence, for instance, introverted and self-confident students are prone to anxiety because they are not good at communicating with others, are afraid to take part in English practice actively, and are nervous when speaking; fear of negative evaluation can also lead to anxiety; fear of making mistakes, caring about others' opinions and worrying about negative evaluation are common psychological phenomena in English learning. Furthermore, examination anxiety is another very common phenomenon among college students, many students cannot treat the exam correctly and worry about failing the exam. Some students always put too much emphasis on the test results, and the mental pressure is too great. Owing to so many anxieties and worries, it is easy to cause excessive tension beyond the psychological load. Therefore, how to reduce anxiety in English learning is crucial in alleviating English learning burnout syndrome. As college students, if we want to reduce anxiety in English learning, we should first encourage ourselves, refuel ourselves and say to us "I can do it", and master good learning methods, develop good learning habits, pay attention to listening, speaking, reading and writing, which will help us in improving English learning while reducing anxiety, and then alleviating learning burnout, or even getting interested in English learning again.

\section{CONCLUSION, LIMITATIONS AND SUGGESTIONS FOR FURTHER STUDIES}

Take all the things into consideration, this paper analyzed the causes of non-English majors' learning burnout syndrome in English learning and proposed some solutions of how to solve the burnout syndrome, it hoped to help both the college English teachers and the non- English majors to have a better understanding, and grasp how to alleviate or even avoid the occurrence of burnout syndrome in the process of teaching and learning, and what's more, with understanding of the causes of the learning burnout syndrome, teachers can stimulate and strengthen students' interest in learning English, promote English teaching from various specific factors affecting students' learning in the actual teaching process, while students can also adjust their interest in learning English and renew their enthusiasm for learning.

Though the present study has provided a survey detailed description of the non-English majors' learning burnout, there are still some limitations of the study. Having the limitations in mind, suggestions for further research, therefore, can be put forward at the same time in order to achieve a better effect in teaching and learning English. For example, being time limitation and practical restrictions (the survey only confined to sophomore and freshman students in one university), therefore, the statistics need to be further collected in further studies; more instruments should be used in the investigation if a further research is being made. Despite of the restraints of the study, it is hoped that it can offer some guidelines for further studies in this area.

\section{REFERENCES}

[1] Bouras N, Holt G. (2007). Psychiatric and Behavioral Disorders in Intellectual and Developmental Disabilities (2nd ed.). New York: Cambridge University Press. https://en.wikipedia.org/wiki/Anxiety. (accessed 17/4/2019).

[2] Freudenberger, H.J. \& J. (1974). Staff burnout. Journal of Social Issues, 30,159-165.

[3] Greene, Graham. (1961). A Burnt-Out Case. New York (Amer. ed.): The Viking Press. p. vii-viii.

[4] Leiter, M.P; Maslach, C. (1999). Six areas of worklife: A model of the organizational context of burnout. Journal of Health and Human Resources Administration, 21, 472-489.

[5] Lian Rong, Yang Lixian, Wu Lanhua. (2005). The Relationship Between College Students' Professional Commitment, Learning Burnout and Scale Compilation. Acta Psychologica Sinica, Beijing: Science Press. 5, 632-636.

[6] Maslach, C.; Jackson, S.E. (1981). The Measurement of Experienced Burnout. Journal of Occupational Behavior. 2, 99-113. 
[7] Maslach, C. (1976). Burned-Out. Human Behavior. 5, 7-22.

[8] Maslach, C., Schaufeli, W.B., \& Leiter, M. P. (2001). Job Burnout. Annual Review of Psychology. 52, 397-422.

[9] Meier, S. F. \& Schneck, R. R. (1985). The Burned-out College Student: A Descriptive Profile. Journal of College Student Personal. 26 (1): 63-69.

[10] Pines, A. \& Kafry, D. (1980). Tedium in College. Paper Presented at the Western Psychological Association Meeting, Honolulu, Hawaii. (ERIC Document Reproduction Service NO. ED199210.)

[11] Seligman ME, Walker EF, Rosenhan DL. Abnormal psychology (4th ed.). New York: W.W. Norton \& Company. https://en.wikipedia.org/wiki/Anxiety. (accessed 17/4/2019).

[12] Yang Tao. (2015). Research on the Relationship between Foreign Language Learning Burnout and Motivation. Beijing: Science Press.7, 187.

[13] Zhu Zhihong. (2008). Attribution Survey of English Learning Failure of Non-English Majors, Journal of Shijiazhuang Railway Vocational and Technical College. Shijiazhuang: Shijiazhuang Railway Vocational and Technical College. 2, 26.

Yaoqin Zhang (1982 -), female, was born in Linyi, Shandong Province, China. She received her Master's degree in language and literature in Sichuan International Studies University in 2007.

She is currently working as a lecturer in Foreign Languages College of Anhui University of Science and Technology, her research interests include English Language and Literature.

She is a member of the Foreign Language Educational Technology Committee. 